\title{
PROSTORSIKE ZNAČILNOSTI IN SPREMEMBE JANČ Z OKOLICO
}

Zvonimir Bratun*

\section{Izvleček:}

V prispevku so predstavljene nekatere reliefne posebnosti Janč z okolico, ki učinkujejo na poselitev in kmetijsko dejavnost. Predstavljene so posledice različnih posegov $v$ prostor in oblikovanje novih prostorskih struktur.

Ključne besede: podeželje, kmetijstvo, relief, kolektivizacija.

\section{CHARACTERISTICS AND CHANGES OF JANČE AREA AND ITS NEIGHBOUR COUNTRYSIDE}

\begin{abstract}
:
In the article relief characteristic of the rural area of Janče hills are represented. Different effects on landscape and agriculture production are happened in last fifty years. Changes of rural landscape are in progress now too.
\end{abstract}

Key words: agriculture, rural area, collectivisation

* Dr. Zvonimir Bratun, predavatelj geografije, Center vojaških šol, Ministrstvo za obrambo, 1000 Ljubljana, Slovenija. 


\section{Uvod}

Pokrajinska podoba Slovenije se hitro spreminja. Podobno velja tudi za širše območje Janč ${ }^{1}$ z okolico. V zadnjih 50 . letih se je območje spremenilo, iz zaostalega in odmaknjenega območja na obrobju Ljubljanske kotline, v privlačno kulturno krajino, ki nudi domačinom in obiskovalcem vrsto prednosti in omogoča primerno življenje kljub skopim naravnim danostim. Vendar je zgodovina območja zaznamovana tudi s poskusi kolektivizacije, odselitvami in zaraščanjem.

\section{Osnovne značilnosti območja}

Obravnavano območje sestavljajo zahodni odrastki Posavskega hribovja v katastrski občini Volavlje. Poimenujemo ga lahko tudi kot Janško hribovje. Obsega območje med potoki Besnico, Gostinco in Malo Reko ter Ljubljanico in Savo. Leži skoraj v osrčju Slovenije na vzhodnem obrobju Ljubljanske kotline. Predstavlja edino večje in sklenjeno podeželsko območje mestne občine Ljubljana.

\section{Naravnogeografske meje}

Obravnavano območja se prekriva z mejami do nedavne krajevne skupnosti Besnica. Sestavlja ga porečje potoka Besnica in zahodni del Janškega hribovja. Predstavlja hribovit in prehoden svet med Ljubljanjsko in Litijsko kotlino na levem bregu reke Save.

Janče, (794m n. v.) je najvišji hrib v zahodnem delu Posavskega hribovja in leži v severovzhodnem delu obravnavanega območja. Na vzhodu meji območje do Bulantinovega vrha (645 m n. v.). Nato prečka dolino Štefulovega potoka in se dvigne na Mancin vrh (747 m n. v.). Po njegovih južnih pobočjih obide Dolgo Brdo. Proti jugu se dvigne na Lanišče $(681 \mathrm{~m}$ n. v.). Zajame območje Brezove Ravni in obkroži Prežganje (cerkev Sv. Marjete 658 m n. v.) z vzhodne strani. Nad pobočji Reke se dvigne na preval in razvodje z Velikim potokom. Od tu se meja območja usmeri proti

\footnotetext{
1 Janče so najvišji vrh zahodnega dela Posavskega hribovja. Zaradi bližine Ljubljane, lepe razgledne točke in izjemne kulturne krajine so cilj številnih obiskovalcev in turistov. Zato so postale simbolno ime za širše območje med Ljubljano in Litijo. V prispevku so predstavljene nekatere sedanje značilnosti tega območja in spremembe v kulturni krajini, ki pripada mestni občini Ljubljana.
} 
zahodu po razvodju med Besnico in Velikim potokom. Na Teličarju $(651 \mathrm{~m}$ n. v.) zavije proti severozahodu v dolino Javorske reke, jo prečka in se po jugozahodnih pobočjih Žagarskega vrha spusti na preval Pečar (460 m n. v.), tik nad skrajnimi južnimi obrobji Ljubljanskega polja. Po Kašeljskem griču se spusti v dolino Besnice in jo prečka pri Tinčkovem travniku. Od tu se dvigne proti severu na Španov vrh (559 m n. v.), prečka Gradolski potok in se dvigne do razvodja z Gostinco na Malem Brovcu (610 m n. v.). Nato poteka meja po severnih pobočjih hribovitega hrbta Vnajnarjev nad Gostinco s pritoki. Prečka Lepo drago in se vzpne na Seten brdo. Od tu zavije proti severovzhodu do Lipavčevega griča (642 m n. v.), prečka Slapnico in se vzpne na Bulantinov vrh.

Območje ima obliko nepravilne elipse z razširjenim vzhodnim in ožjim zahodnim delom².

\section{Glavne reliefne značilnosti območja}

Obravnavano območje je zaključena celota, s prepoznavnimi reliefnimi mejami.

Relief je v veliki meri posledica geološke zgradbe celotnega območja. Za območje je značilna jasna geološka ločnica med triasnimi dolomiti in permokarbonskimi skladi na vzhodnem in južnem obrobju doline Besnice.

Slika 1: Usek v pobočje z dolomitno kamnino. (Foto: Z. Bratun, 01. 07. 2001.)

Photo 1:

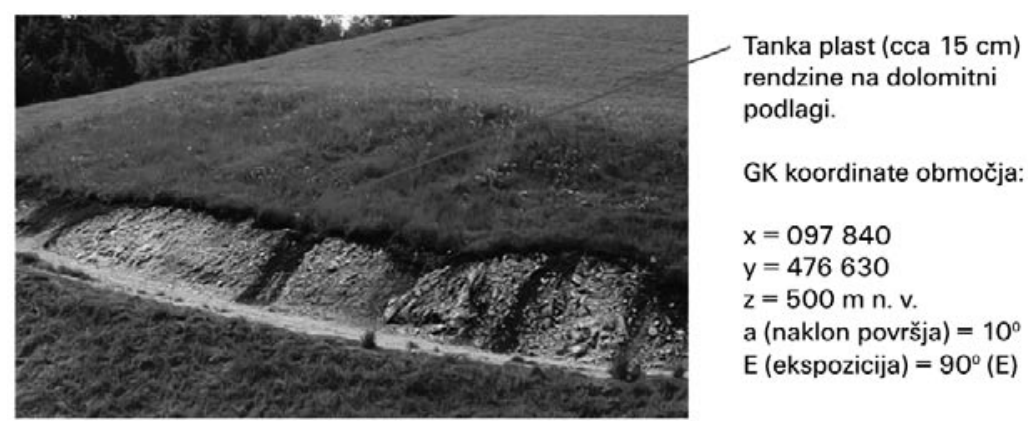

2 Velikost območja lahko ponazorimo tudi s površino dosedanje krajevne skupnosti Besnica, ki je $56,77 \mathrm{~km}^{2}$ (Zavod za statistiko RS, 1991). 
Zato prevladujejo vsi poglavitni genetski tipi in reliefne oblike, ki jih lahko najdemo v osrednji Sloveniji.

Južna in jugovzhodna območja so grajena iz dolomitov in apnencev triasne starosti. Zato so na teh območjih ostanki planotastega in uravnanega sveta najbolj prepoznavni. Vode so prerezale karbonatni pokrov in oblikovale dole s strmimi in težje prehodnimi pobočji. To velja še posebej za jugozahodne dele volaveljske, in zahodne dele prežganjske planote. Trebeljevska planota se zložneje spušča v dolino Besnice, vendar proti zahodu prehaja v strma pobočja proti Malemu Vrhu in Kržareji. Zato je edini reliefno ugoden dostop iz doline Besnice proti Litijski kotlini prek prevala pri Malem Trebeljevem, kjer je tudi razvodje z Reko.

Na jugu obravnavanega območja so reliefne razlike še večje. Strmine in nad njimi uravnani ostanki nekdanje (verjetno pliocenske) planote oblikujejo razgiban svet, ki prehaja iz fluviokrasa v normalni relief obrobja Posavskega hribovja. Namesto dolov se pojavljajo grape in grabni - kakor jim pravijo tudi domačini. Večje so tudi relativne višinske razlike. Naklon površja je večji in bolj enakomeren. Prevladujejo vrednosti med $25^{\circ}$ in $40^{\circ}$. Vmes se iztezajo pomoli ostankov nekdaj bolj uravnanega sveta ${ }^{3}$. Pomoli ter slemena hribov imajo manjše naklone - do $20^{\circ}$. Ta območja je človek v stoletjih iztrgal gozdu in preoblikoval $v$ kmetijske površine.

Smer glavnih slemen poteka od vzhoda proti zahodu. Nanje se vežejo prečna slemena in ostanki teras od severa proti jugu. Isto velja tudi za doline Javorskega potoka, Besnice, Gradolskega potoka in Gostince ter njihovih pritokov. Prevladuje erozijski tip reliefa. Akumulacijskega reliefa je malo. Pojavlja se $v$ dnu razširjenih dolin in v obliki vršajev, ki so oblikovali izgonsko pokrajino. Ta je posebej izrazita $v$ dolini Besnice. Prehodnost reliefa je boljša v smeri vzhod zahod kot pa prečno. Na prečnem prehodu med dolino Save in Višnjice so prevali in sedla, ki jih v ljudskem izrazoslovju poimenujejo tudi “lanišča”.

Dolinski svet prevladuje ob potoku Besnica. Dolina je povprečno široka okoli 200 m. Ponekod je zaradi nasutega materiala tudi širša. Prečne doline so ožje. Razširitve se pojavljajo samo ob izlivih pritokov v Besnico. Celotno območje ki ga gradijo permokarbonski sedimenti, pripada hribovitemu reli-

\footnotetext{
3 Na terenskih vajah s študenti geografije maja leta 1999 smo našli ostanke petih teras na pobočju med dolino Stolnika (GK koordinate izhodiščne točke so: x ( 099 620; y ( 476 200; z ( 400 m n. v.) in Tičence (684 m n. v.).
} 
fu. Na stiku s triasnimi skladi prehaja hribovit relief $v$ planotaste uravnave in delno $v$ fluviokras. Južne, jugovzhodne in jugozahodne ekspozicije $z$ naklonom manjšim od $20^{\circ}$ so primerne tudi za kmetijsko obdelavo.

\section{Poselitev in izkoristek prostora za kmetijsko dejavnost}

Zaradi naravnih danosti in ovir se je poselitev in krčenje gozdnih površin širila postopno. Zgodovinskih zapisov o poselitvi območja je malo. Prav tako ni pomembnejših sodobnih virov ali raziskav. Zato je rekonstrukcija procesa poselitve težavna. Nekaj podatkov nudijo župnijske kronike in pripovedovanja starejših občanov o tem. Po ljudskem izročilu naj bi bila ena najstarejših poselitev na območju sedanje vasi Volavlje in Veliko Trebeljevo, saj sta naselji omenjeni v zapisih Stiškega samostana.

Prvi natančnejši zapis in kartografsko podobo območja predstavlja Jožefinska vojaška karta ${ }^{4}$. Iz nje lahko razberemo značilnosti tedanjih naselij in kmetijskih površin.

Naslednji primeren vir je Krajevni leksikon Dravske banovine, ki ga je izdala Zveza za tujski promet za Slovenijo v Ljubljani leta 1937. Iz njega lahko razberemo podatke za posamezna naselja in opis pomembnejših kmetijskih dejavnosti za posamezne kraje tedanje občine Trebeljevo ${ }^{5}$.

Sedanjo podobo območja predstavlja 14 vasi. Po popisu iz leta 1991 je bil na celotnem območju krajevne skupnosti Besnica 701 prebivalec.

Pri analizi poselitvenih območij se lahko poslužujemo tudi drugih - modernejših tehnik. Med njimi izstopa tehnika daljinske zaznave, kombinirana z računalniško obdelavo reliefnih parametrov. Iz podatkov, pridobljenih $s$ pomočjo daljinske zaznave (Statistični GIS pokrovnosti in rabe tal - stanje $1997^{6}$ ), je bila ugotovljena meja med kmetijsko in gozdno površino. Z računalniško analizo je bila izločena celotna gozdna površina. Ostala površina je bila obdelana s pomočjo analize digitalnega modela reliefa (DMR). Osnovna

\footnotetext{
4 V opisu sekcije 191 (Rajšp V. in Ficko M: Slovenija na vojaškem zemljevidu 1763-1787; Opisi 2. zvezek) na strani 30 lahko razberemo glavne značilnosti poselitve območja v 18. stoletju. Je tudi vir za primerjavo s sedanjim stanjem. Obseg kmetijskih površin na karti je večji od današnjega stanja. 5 Podobo tedanje pokrajine lahko zaznamo tudi iz knjige “Občina Trebeljevo skozi čas”, ki jo napisal Bojan Jerlah v samozaložbi leta 1993. Na straneh od 8 do 10 so opisi posameznih krajev in kmetijske dejavnosti območja, ki se v večjem delu prekriva z do nedavno krajevno skupnostjo Besnica. 6 Podrobneje o tem glej članek: Tretjak, Šabiś, Lojoviś, 2000, Uporaba podatkov posnetih z Landsat in Spot sateliti, DELA 15, Vojaška geografija v Sloveniji, Ljubljana (str. 229-240).
} 
Karta 1: Območja kmetijskih in gozdnih površin Janč z okolico.

Map 1:

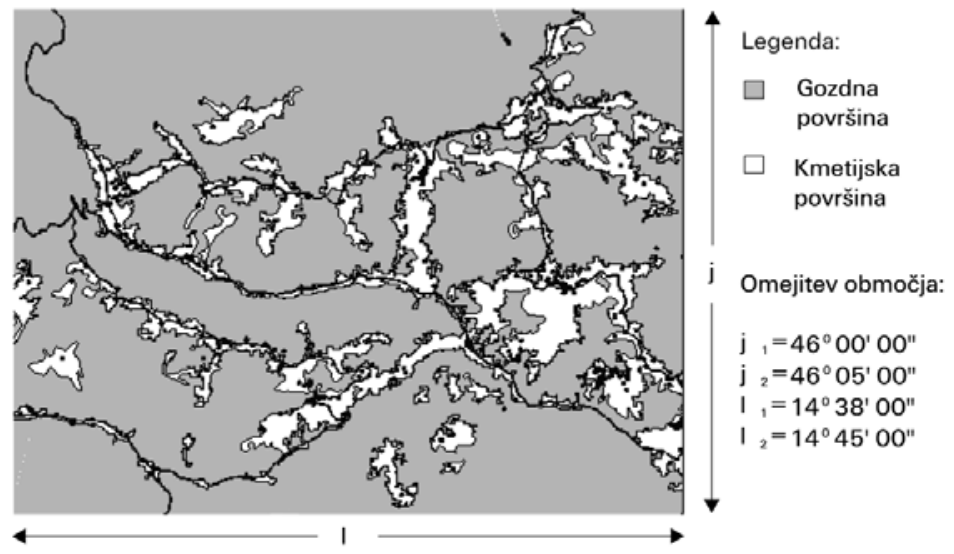

Vir/Source: Statistični Urad Republike Slovenije in Ministrstvo za obrambo RS, SIK, Sektor za GIS in računalniško grafiko. Ljubljana 2001.

Grafikon 1: Prevladujoči višinski pasovi kmetijske površine območja.

Grafp 1:

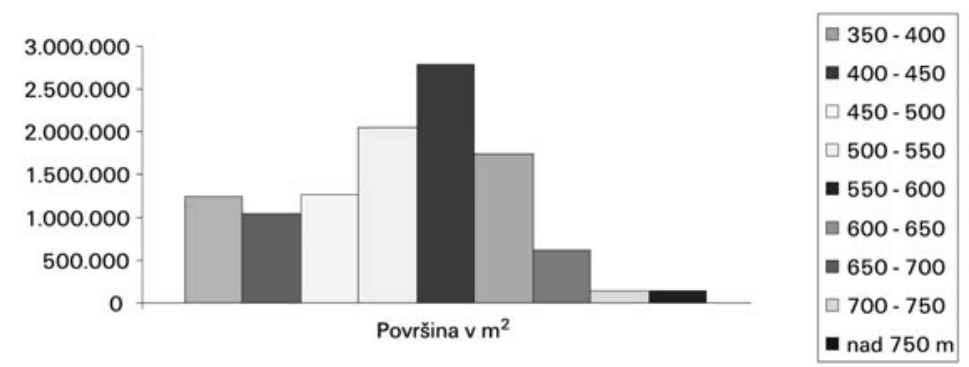

Izračun in podatki: Ministrstvo za obrambo RS, SIK, Sektor za GIS in računalniško grafiko.

enota DMR je bil kvadrat velikosti 20 × $20 \mathrm{~m}$. Izdelani so bili modeli višinskih pasov v skali do $350 \mathrm{~m}$ višine do višjih višin od $750 \mathrm{~m}$. V intervalu med $350 \mathrm{~m}$ in $750 \mathrm{~m}$ je bil posamezen razred velik $50 \mathrm{~m}$ višinske razlike. Računalniška analiza in izračun sta pokazala da $v$ tem intervalu izstopata razred višine med 550 in $600 \mathrm{~m} \mathrm{n}$. v. ter razred višine od 500 do $550 \mathrm{~m} \mathrm{n.} \mathrm{v.}{ }^{7}$ Primerjava poselitve, naklonov površja in višinskih pasov je pokazala, da je

7 Računalniško analizo so naredili delavci Ministrstva za obrambo, SIK, Sektor za GIS in računalniško grafiko 2001 s programskimi orodji Map Info in Arc Info. 
Tabela 1: Prevladujoči naklonski razredi kmetijske površine območja.

Table 1:

\begin{tabular}{|l|l|l|}
\hline Razred & Naklon od do $v^{\circ}$ & Površina v m $^{2}$ \\
\hline 1 & $0-5$ & 1.535 .200 \\
\hline 2 & $5-10$ & 5.377 .200 \\
\hline 3 & $10-15$ & 3.512 .800 \\
\hline 4 & $15-20$ & 2.400 .000 \\
\hline 5 & nad 20 & 2.373 .600 \\
\hline
\end{tabular}

Izračun in podatki: Ministrstvo za obrambo RS, SIK, Sektor za GIS in računalniško grafiko.

Tabela 1: Primerjava poselitve, števila prebivalstva, prevladujočih naklonov površja in višinskih pasov območja.

Table 1:

\begin{tabular}{|c|c|c|c|}
\hline Naselje & Število prebivalcev ${ }^{1}$ & Naklon površja $^{2}$ & Višinski pas ${ }^{3}$ \\
\hline Besnica & 122 & Do $5^{0}$ & Do $350 \mathrm{~m} \mathrm{n} . \mathrm{v}$. \\
\hline Dolgo brdo & 59 & $10^{\circ}$ do $15^{\circ}$ & $450-550 \mathrm{~m} \mathrm{n} . \mathrm{v}$. \\
\hline Jance & 76 & $10^{\circ}$ do $25^{\circ}$ & $650-794 \mathrm{mn} . \mathrm{v}$. \\
\hline Javor & 128 & $10^{0}$ do $25^{\circ}$ & $450-650 \mathrm{~m} \mathrm{n} . \mathrm{v}$. \\
\hline Mali Vrh pri Prežganju & 33 & $15^{\circ}$ do $25^{\circ}$ & $600-700 \mathrm{~m} \mathrm{n.v.}$ \\
\hline Malo Trebeljevo & 49 & $5^{0}$ do $10^{0}$ & $450-600 \mathrm{~m} \mathrm{n} . \mathrm{v}$. \\
\hline Prežganje & 71 & $10^{\circ}$ do $20^{\circ}$ & $500-650 \mathrm{~m} \mathrm{n} . \mathrm{v}$. \\
\hline Ravno Brdo & 28 & $10^{\circ}$ do $25^{\circ}$ & $550-600 \mathrm{~m} \mathrm{n} . \mathrm{v}$. \\
\hline Tuji Grm & 41 & $10^{\circ}$ do $25^{\circ}$ & $650-700 \mathrm{~m} \mathrm{n} . \mathrm{v}$. \\
\hline Veliko Trebeljevo & 62 & $5^{\circ}$ do $10^{0}$ & $500-550 \mathrm{~m} \mathrm{n} . \mathrm{v}$. \\
\hline Vnajnarje & 99 & $5^{\circ}$ do $20^{\circ}$ & $400-650 \mathrm{~m} \mathrm{n} . \mathrm{v}$. \\
\hline Volavlje & 13 & $5^{0}$ do $15^{0}$ & $550-650 \mathrm{~m} \mathrm{n} . \mathrm{v}$. \\
\hline Zgornja Besnica & 72 & Do $5^{0}$ & $350-450 \mathrm{~m} \mathrm{n} . \mathrm{v}$. \\
\hline
\end{tabular}

1) Po podatkih Popisa prebivalstva Slovenije iz leta 1991.

2), 3) Po podatkih iz Državne topografske karte RS 1: 25000 za potrebe obrambe, Republika Slovenija Ministrstvo za obrambo, 1996 in Ministrstvo za obrambo, SIK, Sektor za GIS in računalniško grafiko 2001 . 
poselitev območja je zgoščena v višinskem pasu od 500 do $650 \mathrm{~m}$ n. v. Naklon površja zaradi velike reliefne razgibanosti bolj niha.

Iz podatkov v Tabeli 2 lahko sklepamo da izstopa interval 100 do 200. Pri tem je potrebno poudariti, da so naselja zgoščena na območja z večjim naklonom ${ }^{8}$, pripadajoče kmetijske površine - še zlasti njive, pa na območjih z manjšim naklonom.

Prostorske spremembe območja so bile še posebej izrazite v zadnjih 50. letih. Procesa industralizacije in kolektivizacije sta zaznamovala drugo polovico 20. stoletja.

\section{Kolektivizacija in oblikovanja kmetijskih zadrug}

Med najbolj izrazite procese, ki so temeljito spremenili pokrajino in življenje na vasi spada tudi kolektivizacija. Nasilno uvajanje sprememb in oblikovanje sadjarskih zadrug v letih od 1954 do 1965 so povzročili razpad tradicionalnega kmetijskega življenja in obdelovanja zemlje v izbranih območjih. Med njimi izstopata primera vasi Volavlje in Javor. Kljub geološki in reliefni različnosti sta bili obe vasi izbrani za kolektivizacijski poseg rigolanja površin in oblikovanju območja za saditev sadnega drevja. Skupna reliefna značilnost obeh območij je bila južna in jugozahodna ekspozicija površin, ki so jih spremenili v plantažne nasade jablan.

Njive kmetov iz osrednjega dela vasi Javor ${ }^{9}$ so preoblikovali v nasad z buldožerji. Manjše število kmetov, ki so prostovoljno podpisali oddajo svoje posesti zadrugi, so razlastili. Dobili so manjšo denarno odškodnino. Spremembe so bile vpisane $v$ zemljiške knjige. Nekaj prebivalcev (njihovo število je nihalo od 2 do 5) je dobilo začasno zaposlitev pri vzdrževalnih delih $v$ nasadu oziroma $v$ novo oblikovani kmetijski zadrugi. Večina kmetov se je posegu upirala. Nekaj jih je bilo celo zaprtih. Tako je vas Javor doživela dva večja demografska šoka. Prvi je bil posledica padlih med 2. sv. vojno in pobitih po osvoboditvi. Drugi šok je bil posledica razlastitve in odvzema zemlje. Zato so mladi odšli v ljubljanske tovarne, na kmetijah pa so ostali

8 To velja za naselja Gabrje, Javor, Mali Vrh pri Prežganju in Tuji Grm.

9 Obseg plantažnega nasada na južnih pobočjih Javora, je razviden tudi iz Državne topografske karte RS 1: 25 000, sekcija Dolsko 117, za potrebe obrambe, Republika Slovenija Ministrstvo za obrambo, 1996. Iz podatkov na karti lahko ocenimo velikost tedanjega nasada. V dolžino je meril okoli $600 \mathrm{~m}$ in v širino $400 \mathrm{~m}$ zračne razdalje. 
obubožani in ostareli prebivalci brez večine njiv in travnikov. Podobna je bila usoda vasi Volavlje ${ }^{10}$.

Po desetih letih so nasad zaradi nerentabilnosti opustili, kmetje so dobili zemljo nazaj, vendar je bila škoda že povzročena. Kljub vztrajanju kmetov po vrnitvi površine nasada $v$ stanje in obliko pred tem, je opuščen nasad $v$ večjem delu še danes spomenik nasilni kolektivizaciji.

Iz poročil tedanje zadruge naj bi bili krivi za nerentabilnost nasada predvsem objektivni vzroki. Prvo leto je mlade sadike obglodala divjad. Svoje je naredil tudi snegolom. Zaradi pomanjkanja škropiv so drevesa napadle bolezni. Kolektivizacijski poseg se je neslavno končal po desetih letih.

Slika 2: Območje vasi Javor. (Foto: Z. Bratun, 01. 07. 2001)

Photo 2:

\section{Vračanje zemlje in usmeritev kmetijske proizvodnje}

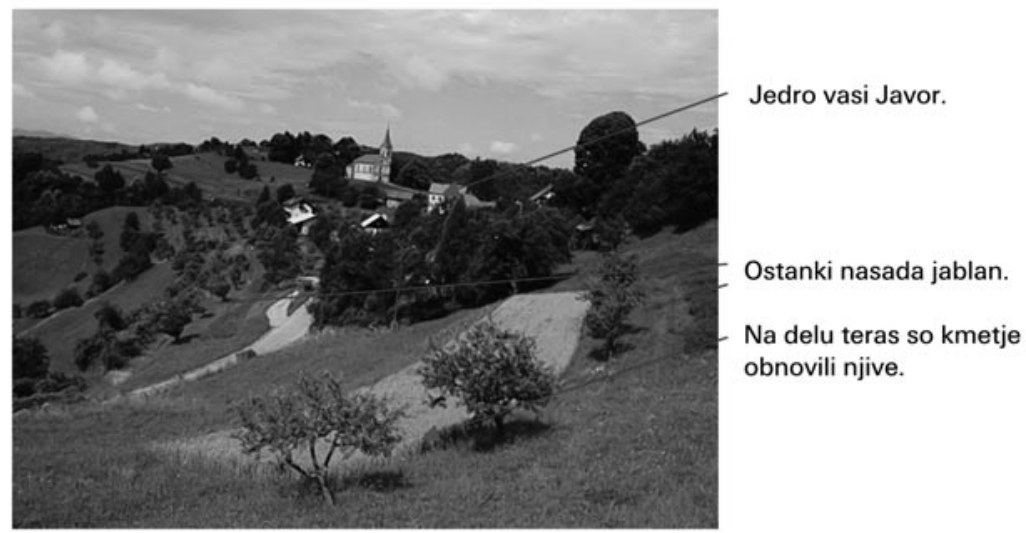

Vrnjena zemlja ni bila več obdelana. V ostankih nasada so kmetje kosili zgolj travo za seno. Tradicionalna kmetijska proizvodnja se je umaknila živinoreji kot novi usmeritvi v kmetijski pridelavi. Po letu 1970 so na območju Besnice pričeli z organizirano oddajo mleka. Njive so kmetje v večjem delu

9 Obseg plantažnega nasada na južnih pobočjih Javora, je razviden tudi iz Državne topografske karte RS 1: 25 000, sekcija Dolsko 117, za potrebe obrambe, Republika Slovenija Ministrstvo za obrambo, 1996. Iz podatkov na karti lahko ocenimo velikost tedanjega nasada. $V$ dolžino je meril okoli $600 \mathrm{~m}$ in v širino $400 \mathrm{~m}$ zračne razdalje.

10 Ustni vir: Terezija Bratun, Vnajnarje 2, dne: 10. 07. 2001. 
spremenili v travišča. Pridelka žit je bilo čedalje manj. Zadruge so nudile ugodne pogoje za nakup traktorjev. Kmetije so se hitro modernizirale. Vlečno živino je nadomestil traktor. To je pomenilo nove posege v kmetijske površine. Naredili so poljske poti, površine primerne za strojno obdelavo so rigolali in opuščali košenice, ki so bile zaradi velikih naklonov neprimerne za strojno košnjo. Ker je celotno območje blizu Ljubljane so pričeli tudi z vzpodbujanjem pridelave jagod. Prva organizirana in strokovna razstava jagod na tem območju je bila leta 1972 na Prežganju. Večina mladih je po končani osnovni šoli nadaljevala z izobraževanjem v srednjih šolah. Večji del kmetov je poiskal delo $v$ tovarnah. Delo na kmetiji je postalo dopolnilna dejavnost.

\section{Zaraščanje kmetijskih površin}

Zaraščanje sovpada z začetkom modernizacije kmetij in odhodom mladine na delo v Ljubljano. Obseg zaraščenosti, vrsta in velikost dreves nam nudijo osnovne parametre pri določanju območij, ki jih je zajel ta proces. Ker je premer debla posameznega drevesa vsako leto povprečno večji za en $\mathrm{cm}$ in drevo zraste $v$ višino okoli $50 \mathrm{~cm}$ lahko na podlagi spomina domačinov, topografskih kart in terenskega dela ugotavljamo obseg in začetek poraščanja kmetijskih površin. Na obravnavanem območju so bile izpostavljene procesu prelogizacije predvsem strme košenice in pašniki. Danes se opuščajo tudi vse kmetijske površine, kjer ne morejo obdelovati tal ali kosi-

Slika 3: Ostanki košenice na pobočju Aslivke. (Foto: Z. Bratun, 01. 07. 2001).

\section{Photo 3:}

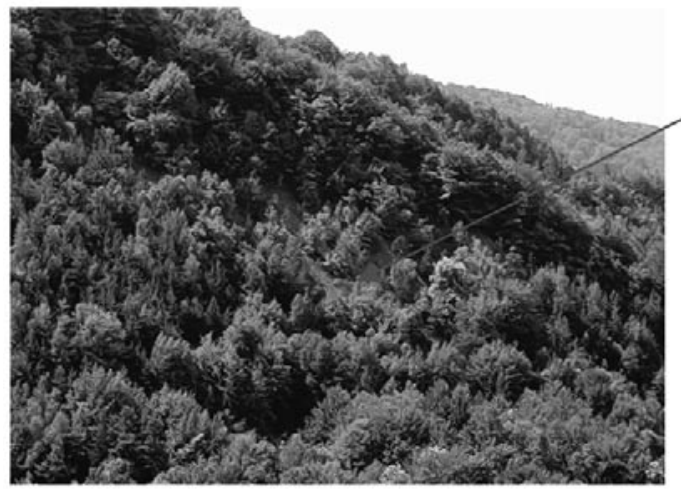

Zaraščanje košenice s pionirskim gozdom

GK koordinate območja:

$\mathrm{x}=097900$

$y=476860$

$\mathrm{z}=500 \mathrm{~m} \mathrm{n}$. v.

I (naklon površja) $=30^{\circ}$

$E($ ekspozicija $)=315^{\circ}(\mathrm{NW})$ 
ti travnikov in pašnikov s traktorji. To pomeni, da bo v naslednjih desetletjih zaraščanje zajelo večino kmetijske površine, z naklonom večjim od 150. Drugi razlog za zaraščanje pašniških površin je $v$ preusmeritvi znatnega dela kmetij $v$ pridelavo sadja. To tudi pomeni manjšanje staleža živine v hlevih za četrtino.

\section{Pomen območja za vojaško obrambne potrebe}

Obravnavano območje je odmaknjeno od glavnih prometnic in ločeno od Ljubljanske kotline z obrobjem Janškega hribovja. Zato je bilo v preteklosti pomemben vir prehrane za mestno prebivalstvo $v$ mirnem času in izrednih razmerah. äe posebej je bilo to izrazito $v$ času 2. svetovne vojne in neposredno po njej, v času tako imenovane "obvezne oddaje". Preko obravnavanega območja je v času 2. svetovne vojne vodila glavna preskrbovalna pot s Štajerske na Dolenjsko.

\section{Obdobje zasnove splošne ljudske obrambe in družbene samozaščite}

Po letu 1970 so tudi na obravnavanem območju pričeli z izgradnjo sistema splošne ljudske obrambe. V Besnici so postavili črpalko in vkopali cisterne za dizelsko gorivo. Večina vasi je dobila telefonsko povezavo. Na Jančah so postavili repetitor za potrebe upravnih zvez. Kmetje so dobivali subvencije za rejo govedi. Začeli so z eksperimentalnim uvajanjem novih poljščin kot je soja.

Zato so bile samooskrbne zmogljivosti območja nad potrebami domačinov. V upravnih organih za obrambo so predvidevali možnost oskrbe še za dodatnih 300 ljudi na leto.

\section{Samooskrbne zmogljivosti območja danes}

Zaradi spremembe političnega sistema in opustitve sistema splošne ljudske obrambe je nastala praznina. Ukinjene so bile podpore za povečan stalež živine in nakup semen novih poljščin.

Po letu 1990 so pričeli oživljati območje s programom CRPOV (celostni razvoj podeželja in vasi). Zasuk v pridelavi je bil radikalen. Usmeritev v sad- 
Slika 3: Kal pri kmetiji Bratun, Vnajnarje 2. (Foto: Z. Bratun, 01. 07. 2001).

Photo 3:

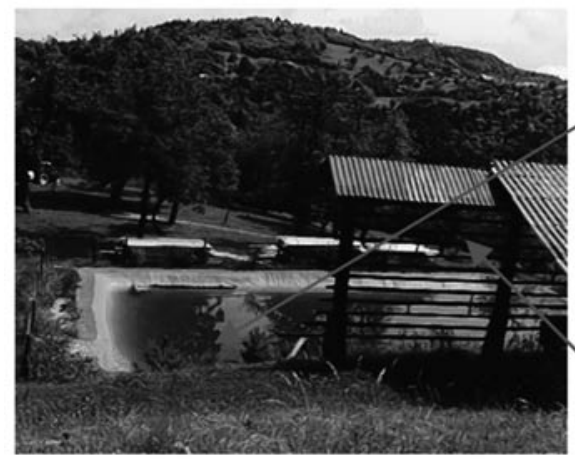

Kal je izkopana jama, obložena z vododržno folijo. Vanjo se steka deževnica s streh po ceveh. Iz kali so napeljane namakalne cevi do njiv in sadovnjakov.

Prazen kozolec je simbol sodobne kmetije. Sušenje sena ali žitnih snopov v kozolcih so kmetje opustili zaradi zamudnega in predvsem ročnega dela.

jarstvo in jagodičevje je povzročil velik upad staleža živine. Prašičev praktično ne gojijo več. Razmišlja se o ukinitvi organiziranega zbiranja mleka. Število govedi se je zmanjšalo za eno tretjino. éit ne sejejo več. Kruh vozijo in prodajajo zasebni peki kar po domovih. Opušča se setev koruze za silažo. Delni vzrok temu je tudi škoda, ki jo povzroča divjad na poljih. Še pred 15 leti so kmetje pridelali višek hrane. Danes je postalo območje popolnoma odvisno od preskrbe s krušnimi žiti in delno odvisno od preskrbe z mesom. Zaradi usmeritve v sadjarstvo so bile zgrajene sušilnice sadja in hladilnice, ki v izrednih razmerah omogočajo skladiščenje dodatnih količin hrane.

Druga posebnost predstavljajo kali - zbiralniki deževnice v obliki bazenov, namenjeni za namakanje vrtnin in sadovnjakov. Zato sušna obdobja nimajo več pomembnejšega učinka na kakovost in količino pridelkov. Poleg tega imajo kali tudi protipožaren pomen.

Stroji, hlevi in gospodarska poslopja še vedno predstavljajo osnovo za primer nujne in hitre preusmeritve kmetijske dejavnosti v izrednih razmerah. 


\section{Izkoristek območja za morebitne vojaške aktivnosti}

Območje leži izven pomembnejših vojaško geografskih smeri. Njegov pomen je predvsem $v$ možnosti nadzora jugovzhodnega dela Ljubljanske kotline in Ljubljane ${ }^{11} \mathrm{z}$ dominantnih vrhov Janškega hribovja. Slemenasta poselitev in kmetijske površine na grebenih omogočajo uporabo vertikalnega manevra. Poseben pomen območju daje obračališče letal, ki pristajajo na letališču Brnik. Tudi JLA se je zavedala pomena območja. Zato so na območju Starega zidu zgradili kompleks izstrelitvenih ramp za protiletalske rakete. Danes je ta kompleks zapuščn ${ }^{12}$. Dobre cestne povezave omogočajo hiter premik in zasedbo celotnega območja.

\section{Sedanje stanje in možnosti nadaljnjega razvoja}

Sedanje stanje je $v$ veliki meri odsev spremenjenih okoliščin po osamosvojitvi Slovenije. Projekt CRPOV je v veliki meri zaznamoval sedanjo podobo kmetijske pridelave danes. Urejeni so bili številni sadovnjaki. Pridelava jagod je postala donosen posel za večino kmetov. Razširila se je dodatna ponudba izdelkov in proizvodov ter njihova prodaja na kmečkih domovih. $\checkmark$ dolini Besnice so pričeli z vzrejo potočnih postrvi. Pri opuščenem mlinu je

Slika 4: Ribogojnica “Marolte" v Besnici. (Foto: Z. Bratun, 01. 07. 2001).

Photo 4:

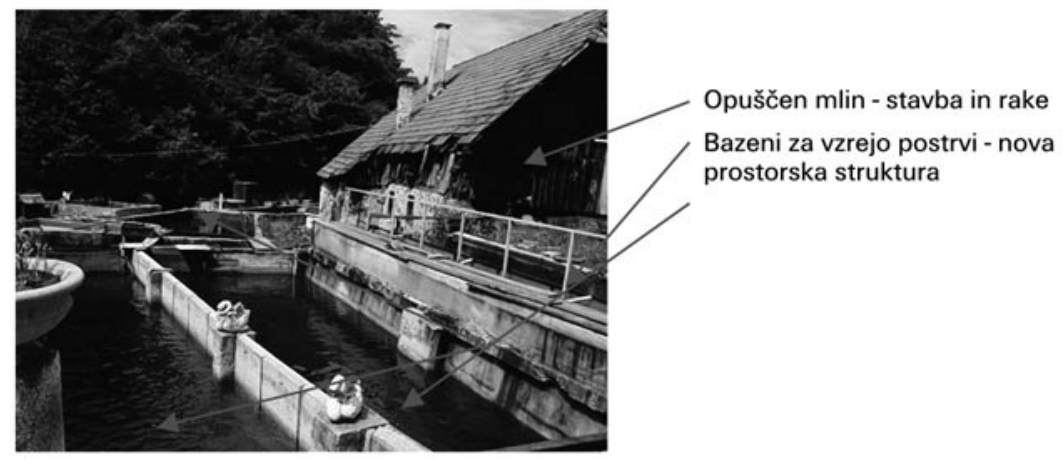

11 Izkušnje iz obleganja in obstreljevanja Sarajeva v vojni v Bosni in Hercegovini med leti 1992 in 1995 bi lahko izkoristil morebitni napadalec tudi z zasedbo dominantnih vrhov Janškega hribovja za nadzor in obstreljevanje Ljubljane.

12 Prisvojili so si ga lovci. Del kompleksa so preuredili za streljanje na glinaste golobe. 
domačin zgradil bazene za vzrejo potočnih postrvi. Nastala je nova prostorska struktura, ki omogoča delo celi družini.

Z ureditvijo "Borovničeve poti" med Podgradom in Jančami, ki vodi po razvodju med Besnico in Gradolskim potokom oziroma Gostinco, so na območju vasi Vnajnarje, Gabrje in Janče postavljeni temelji pohodniškega turizma. Enako velja za "Kostanjevo pot" med Sostrim in Malim Vrhom pri Prežganju.

Še posebej izstopajo prireditve podeželskih praznikov "Jagodne in Kostanjeve nedelje" na Jančah, ki privabljajo veliko število Ljubljančanov in tudi prebivalcev iz drugih predelov Slovenije. Navedene aktivnosti so rezultat radikalne preusmeritve in odpiranja območja.

\section{Zaključek}

Območje obsega pokrajino med potoki Besnico, Gostinco in Malo Reko ter Ljubljanico in Savo. Leži skoraj v osrčju Slovenije na vzhodnem obrobju Ljubljanske kotline. Predstavlja edino večje in sklenjeno podeželsko območje mestne občine Ljubljana. Obravnavano območje je zaključena celota, s prepoznavnimi reliefnimi mejami. Primerjava poselitve, naklonov površja in višinskih pasov je pokazala, da je poselitev območja je zgoščena $v$ višinskem pasu od 500 do $650 \mathrm{~m} \mathrm{n}$. v.

Med najbolj izrazite procese, ki so temeljito spremenili pokrajino in življenje na vasi spada tudi kolektivizacija. Zaraščanje sovpada z začetkom modernizacije kmetij in odhodom mladine na delo $v$ Ljubljano. Danes se opuščajo tudi vse kmetijske površine, kjer ne morejo obdelovati tal ali kositi travnikov in pašnikov s traktorji.

Obravnavano območje je odmaknjeno od glavnih prometnic in ločeno od Ljubljanske kotline z obrobjem Janškega hribovja. Zato je bilo v preteklosti pomemben vir prehrane za mestno prebivalstvo $v$ mirnem času in izrednih razmerah.

Sedanje stanje je v veliki meri odsev spremenjenih okoliščin po osamosvojitvi Slovenije. Urejeni so bili številni sadovnjaki. Pridelava jagod je postala donosen posel za večino kmetov. Razširila se je dodatna ponudba izdelkov in proizvodov ter njihova prodaja na kmečkih domovih. 
Danes predstavlja krajinska podoba z urejenimi in obdelanimi kmetijskimi površinami element privlačnosti. Hitro zaraščanje površin z gozdom na območjih s težjimi obdelovalnimi pogoji krči kmetijsko površino, Izgled pokrajine se izgublja v objemu "zelene smrti".

\section{Summary:}

Area comprehends landscape between creeks Besnica, Gostinca and Mala Reka and rivers Ljubljanica and Sava. It is located almost in the heart of Slovenia on east edge of Ljubljana bassin. It represents the only larger and gathered province of city community of the Ljubljana. Treated region is concluded integrity with recognizable relief borders. Comparison of colonization, angles of surface and altitude zone has shown that colonization of area is higher in altitude zone from 500 to $600 \mathrm{~m}$ height above sea level. Collectivisation was hard process that have radically changed landscape and life on village. Overgrowth areas are coincidences with beginning of transformation of farms. Today most of farm surfaces and landscape are being abandoned because they are not cultivated and grassland cannot cut down with farm tractor. Treated region is located away from main traffic lines and separated from Ljubljana bassin with border of Janče hillside. That is why there was an important source of food for city population in peacetime and unusual circumstances. These days region image represents settled and well-treated element of attraction. Quick overgrowth of difficult accessible farm surfaces with forest is being lost in embracing of "green death".

Karta 2 in 3: Računalniška izrisa višinskih pasov in naklonov kmetijske površine Janč z okolico
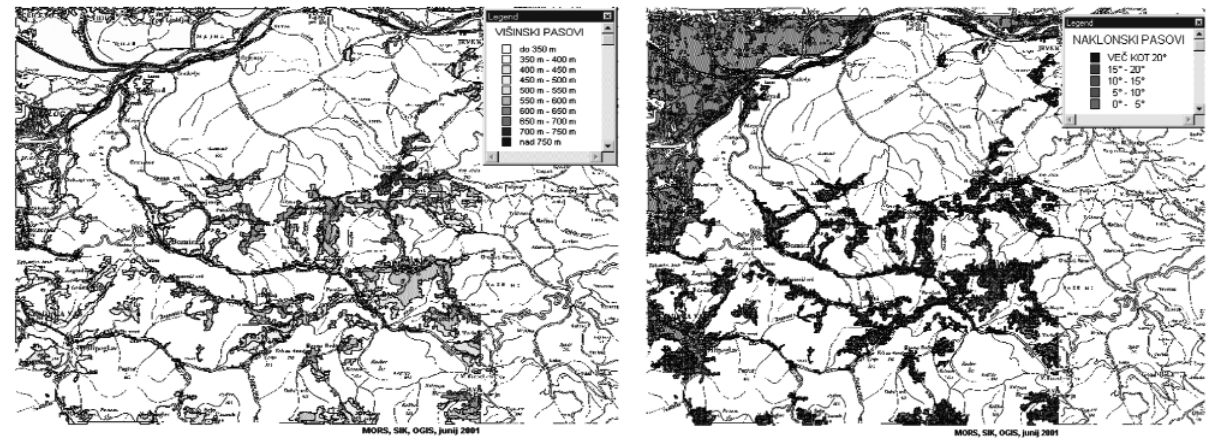

Podatkovna baza: Statistični urad RS in MORS, sektor GIS. Izdelano v MORS, sektor za GIS. 


\section{Viri in literatura}

Bratun, T., 2001. Ustni vir, 02. 07. 2001, Vnajnarje.

Bratun, Z., 1997. Geografski dejavniki državnovarnostnega sistema Republike Slovenije. Doktorska disertacija, Oddelek za geografijo, Filozofska fakulteta, univerza v Ljubljani, Ljubljana.

Jerlah, B., 1993. Občina Trebeljevo skozi čas. Samozaložba, Ljubljana.

Rajšp, V. in Ficko, M., 1996: Slovenija na vojaškem zemljevidu 1763-1787, ZRC SAZU, Karta: Sekcija 191 in Opisi 2. zvezek, stran 30. Ljubljana.

Tretjak, A., Šabić, D. in Lojović, E. H., 2000: Uporaba podatkov posnetih z Landsat in Spot sateliti, DELA 15. Vojaška geografija v Sloveniji, Ljubljana str, 229-240.

2001: Ministrstvo za obrambo, SIK, Sektor za GIS in računalniško grafiko.

1996: Državna topografska karta RS 1: 25 000, sekcija Dolsko 117, za potrebe obrambe, Republika Slovenija Ministrstvo za obrambo, Ljubljana. 